\title{
VALÓSÁG ÉS FIKCIÓ: TÉRI TÁJÉKOZÓDÁS FIZIKAILAG VALÓS ÉS COMPUTER ÁLTAL LÉTREHOZOTT VIRTUÁLIS KÖRNYEZETBEN*
}

\author{
KÁLLAI JÁNOS ${ }^{1,2}$ \\ ${ }^{1}$ Pécsi Tudományegyetem Általános Orvostudományi Kar Magatartástudományi Intézet \\ ${ }^{2}$ Pécsi Tudományegyetem Bölcsészettudományi Kar Pszichológiai Intézet \\ E-mail: janos.kallai@aok.pte.hu
}

Beérkezett: 2015. június 02. - Elfogadva: 2015. június 25.

\begin{abstract}
Az összefoglaló rövid áttekintést ad a téri tájékozódás kognitív idegtudományi kutatásának elözményeiröl, bemutatja meghatározó egyéniségeit. A neuropszichológiai szemelvények és a helytanulás tudománytörténeti ismertetése után kitér a helyhez kötött emlékezés többdimenziós természetére. A teret különbözö modalitású ingerek alkotják, amelyek mind alkotórészei egy történetnek, amit magunk szö̈vünk mások inspirációi alapján. Megvizsgáljuk az egocentrikus-allocentrikus reprezentációk dinamikai változásait, valamint a figyelmi elötér és háttér klinikai vonzatait, a szorongás és a téri navigáció kölcsönhatásait. A felsorakoztatott adatok felhívják a figyelmet a jövő évtizedeket érintő néhány aktuális kérdésre. Hogyan alkalmazkodjunk a tömegesen megjelenő computer által létrehozott valóságokhoz? A tér általános szemlélete mennyiben segíti az én elhatárolódásra vagy fúzióra törekvö automatizmusait? Mit kínál nekünk, szakembereknek a taktilis, auditív, proprioceptív ingereket is alkalmazó fejlettebb virtuális realitás?
\end{abstract}

Kulcsszavak: egocentrikus, allocentrikus, helytanulás, szorongás, navigációs stratégiák, agorafóbia

* Az alábbi összefoglaló a Magyar Pszichológiai Társaság Egerben rendezett, XXIV. Országos Tudományos Nagygyủlésén elhangzott Grastyán Endre-emlékelőadás alapján készült.

Az összefoglaló elkészítését az OTKA T-106176 támogatta. 


\section{BEVEZETŐ}

Az összefoglaló bevezetőjében két kiváló kutató munkája előtt szeretnék tisztelegni. Grastyán Endre a Pécsi Tudományegyetem Élettani Intézetének hajdani vezetője, élen járt a téri környezet felderítését kísérő elektrofiziológiai mutatók meghatározásában, és a hippokampusz tanulásban játszott szerepének felderítésében. John O'Keefe, az University College London munkatársa pedig, aki kutatótársaival - May-Britt Moserrel és Edvard Moserrel - együtt 2014-ben elnyerte a fiziológia és medicina művelőinek adományozott Nobel-díjat, szintén a hippokampuszkutatásában szerzett elévülhetetlen érdemeket. O’Keefe munkacsoportja felderítette, hogy a hippokampuszban a tér bizonyos pontjaira specifikusan reagáló sejtek helyezkednek el. Az általa felfedezett helysejtek aktivitásmintázata térképszerűen követi a megfigyelő szem előtt lévő fizikai tér struktúráját (O'KeEFE és Dostrovsky, 1971). A felfedezés előzményei között meg kell említenünk Grastyán Endrének a hippokampusz működését leíró vizsgálatainak eredményeit. GRASTYÁN, Lissák, MADARÁsz és DONHOFFER (1959) megállapították, hogy egy adott helyen lévő orientációs reakciót kiváltó inger megközelítésekor théta elektrofiziológiai aktivitás jelenik meg az hippokampuszban. Az állat addigi tevékenységét megszakítva, célzottan megközelíti az orientációs reakciót kiváltó ingert, tapogatja, nézegeti, szagolgatja, azaz multimodális kapcsolatot létesítve explorálja, és ezzel a környezet egy adott pontjára lehorgonyozza a tapasztalatait. A hippokampális théta aktivitás téri megismerésben és a tanulásban betöltött szerepét a későbbiekben BUzSÁKI $(2002,2011)$ definiálta részletesebben. Talán nem véletlen, hogy az O'Keefe és munkatársai által szerkesztett a The Hippocampus Book (ANDERSEN, Morris, AMARAL, Bliss és O’KeEFe, 2007) részletesen idézi ezeket a munkákat, valamint további magyar kutatók - Freund Tamás, Somogyi Péter és Buzsáki György - publikációit. John O’Keefe a Nobel-díj átvételekor tartott előadásában külön kiemelte, hogy Buzsáki György théta-hullámokkal kapcsolatos felfedezései jelentős támaszt nyújtottak számára a hippokampális navigációs rendszer neurális organizációjának megértésében.

Az 1960-as években a robbanásszerüen fejlődő helytanulási vizsgálatok alapvetően Edward Tolman munkáira támaszkodtak. TOLMAN (1948) táplálékot kereső állatok viselkedését tanulmányozta különböző formájú útvesztőkben. Megállapította, hogy célvezérelt lokomóció során az állatok a cél elérése érdekében megtanulják, hol és mikor kell egy adott útvesztö-elágazásban jobbra vagy balra fordulniuk. Az 1940-es évekre jellemző viselkedésmegerősítési paradigmában gondolkodva tehát az állat az egymást követő inger-válasz tanulás szukcesszív rendjét a navigációs pontoknál megerősített válaszszelekció alapján hajtja végre. Az állat többnyire útvonalakat tanul meg, és útvonal-követési stratégiát alkalmaz, amelynek eredményét egocentrikus referenciára támaszkodó reprezentációkban tárolja. Az állatok problémamegoldó viselkedésének vizsgálata során a korábban alkalmazott egyszerủ labirintust sugár alakú labirintussal helyettesítették. A sugár alakú labirintusban az állatot megakadályozták abban, hogy a labirintusban korábban megtanult módon jusson eleséghez. Lezárták a „jó” út felé vezető bejáratot, de alternatív útvonalakat biztosítottak a cél megközelítéséhez. Arra ügyeltek, hogy a korábbi kiindulópont- 
hoz képest a céltárgy távolsága és égtáj szerinti pozíciója (észak-nyugat) megegyezzen a korábbival. A futási eredmények azt mutatták, hogy a gyakorlott állatok többsége a lezárt ,jó” útvonal ellenére már az első próba alkalmával nagy valószínűséggel megtalálta a céltárgy helye felé vezető alternatív útvonalat. A korábbi labirintusban szerzett előzetes tapasztalatok alapján mintha rögzítették volna a környezet topográfiáját, az útvonaltanulás során, mellékesen egy térképet alakítottak ki a környezetükről, amely probléma esetén alternatív lehetőségként segítette őket a navigációban. Ebben az esetben, a lehetséges útvonalak figyelembevételével, saját útvonaluktól viszonylag független térkép alapú, allocentrikus megközelitési stratégiát követtek. Mindezek alapján azonnal felvetődött három teoretikus kérdés: 1. Vajon a téri tanulás Gestalt által irányított belátásos vagy megerősítéselvű konstrukció eredménye? 2. Mikor, melyik és milyen feladatokban kerül előtérbe? 3. Mennyiben azonosak a hátterükben álló idegrendszeri hálózatok?

A kérdésekre adandó válaszokhoz, neurológiai léziót szenvedett személyek célzott vizsgálatán, állatoknál alkalmazott ablatív beavatkozások és azok következményét felmérő empirikus vizsgálóeszközök kidolgozásán és az állatok viselkedésének kifinomult, idegsejt-aktivitás elemzésén keresztül vezetett az út. ${ }^{1} \mathrm{Az}$ idegsejt-aktivitás vizsgálatára alkalmas mélyelektródás eljárások kidolgozása tette lehetővé a navigáció és a fizikai környezet automatikus leképezésének sejtszintű experimentális vizsgálatát. Ebben az időszakban a Montrèal McGill egyetem pszichológiai intézetének vezetője, Donald Hebb volt, aki laboratóriumában a legújabb mikroelektródás elektrofiziológiai módszereket alkalmazta. Intézete vonzotta az interdiszciplináris képességekkel rendelkező pszichológusokat. Intézete a kognitív idegtudomány kiemelkedő interdiszciplináris műhelye volt. ${ }^{2}$ A 1960-as évek végén ebben az intézetben volt PhD-doktorandusz O'Keefe és kutatótársa, Lynn Nadel, akik a téri memória és a hippokampális funkciók kapcsolatát vizsgálták. ${ }^{3}$ Nevük-

1 Ezen a helyen a téri tájékozódási zavarok és a neurológiai léziók kapcsolatával nem foglakozom. A jól ismert HM eset, amelyet még az 1950-es években SCOVILLE és MiLNER (1957), a McGill Egyetem neurológiai osztályán dolgozó neurológus és neuropszichológus írt le először, egyértelműen jelzi, hogy a humán hippokampusz léziója az epizodikus memória sérülésével együtt jelentős zavarokat okoz a téri tájékozódásban, az ingerek kontextusának emlékezeti megtartásában. Mindemellett azonban a procedurális memória részben sértetlen marad. Ez a lelet volt az egyik kiindulópontja a többszörös emlékezeti modellek megszületésének.

2 Ebben az időszakban a McGill Neurológiai és Idegsebészeti Intézetét (MNI) Wilder Penfield vezette, aki gyógyszeres kezelésre nem reagáló epilepsziás betegek idegsebészeti ellátása során, éber személyek agykérgének elektromos ingerlésével feltérképezte az egyes kognitív funkciók irányításában részt vevő agyi területeket. Szállóigévé vált mondata szerint: „Az a baj a neurológiával, hogy azon keresztül nem lehet megérteni, milyen az ember a maga valóságában.” Neuropszichológusokkal, emlékezetkutatókkal vette körül magát, és közvetlen munkakapcsolatot ápolt D. O. Hebb pszichológiai intézetében dolgozó munkatársakkal (B. Milner, J. Olds, R. Melzack). OLDS és MiLnER (1953) megállapította, hogy az agy szeptális területére beépített elektródán keresztül adott ingerlés hatására az állat következetesen visszatér arra a területre, ahol a kellemes hatású ingerlés időszakában korábban tartózkodott.

3 1967-ben O’Keefe Melczak doktoranduszaként ismerkedett meg az egysejt-elvezetéses technikával, és itt kezdte el akkori TDK-s hallgatójával (Dostrovsky, J.) azokat a vizsgálatokat, amelyekből 1971-ben az első, jelentős figyelmet kiváltó eredmények születtek. Vendégkutatóként ebben az időben ott tartózkodott az egyik Grastyán-tanítvány, Szabó Imre (jelenleg a PTE ÁOK Magatartástudományi Intézet emeritus professzora), aki a későbbiekben szabadon mozgó állatok egysejt-hippokampális aktivitásának telemetriás mérőrendszerének fejlesztésében vett részt. 
höz füződik a kognitív idegtudomány egyik alapműve The hippocampus as a cognitive map (O'KEEFE és NADEL, 1978) címü könyv, amely a tér filozófiai szemléletmódjának bemutatásától a gyermekkori, felnőttkori emlékezés mechanizmusainak elemzésén át a hippokampális egysejtaktivitás-elemzés tapasztalatainak bemutatásával jutott el a kognitív térkép integrált modelljéig. O'KEEFE és DOSTROVSKY The hippocampus as a spatial map címủ 1971-ben megjelent cikkéhez képest eltelt 6-7 év alatt Lynn Nadel tevőleges részvételével zajló kutatások és cikkek után megírt összefoglaló (O'KEEFE és NADEL, 1978) címében már jelentős paradigmaváltás érzékelhető. Az 1970-es évektől kezdve megváltozott a helysejtekkel kapcsolatos teoretikus megközelítési módok és a helysejtek szerepe, sok bizonytalanságot maguk után hagyva, egy általános, megismerés-központú reprezentációs modellbe ágyazottan élt tovább. Ennek a teoretikus váltásnak értelemszerủen együtt kellett járnia kutatópályák és megközelítési módok szétválásával is. Egyik oldalon a kognitív térképhez köthető viselkedésleíró, klinikai központú és a fenomenológiai szinten is értelmezhető elgondolások uralkodtak. A másik oldalon viszont a sejtszintű, experimentálisan pontosan definiált téri struktúrákhoz köthető elektrofiziológiai vizsgálatok voltak a meghatározóak.

A történeti bevezető után első lépésben O’Keefe és a későbbiekben hozzá csatlakozó May-Britt Moser neuropszichológus és Edvard Moser idegkutató munkái nyomán a helysejtek és a viselkedéses korrelációk elemzésének eredményeit mutatom be. Azt követően kitérek a Nadel által képviselt helytanulás és téri memóriaelvű magyarázatokra, amelyekhez kiegészítésképpen hozzákapcsolok néhányat a Nadellel közösen végzett vizsgálatainkból, amelyek a téri navigációs stratégiák és egyes affektív zavarok, jelen esetben az agorafóbiás szorongás összefüggéseit mutatják be.

\section{HELYSEJTEK ÉS HELYRÁCSOK}

O’KeEFe és Dostrovsky (1971) patkány hippokampusz dorzális részébe épített elektródákon keresztül nyert elektrofiziológiai adatok alapján keresték a viselkedés (arousal-szint, ivás, evés, alvás, vakarózás, pedálnyomás, lokomóció) és a sejtaktivitás korrelációit. Számos sejtaktivitás, viselkedéskorreláció mellett, olyan idegsejteket azonosított, amelyek csak akkor mutattak intenzív reakciót, amikor a rágcsáló a vizsgálati helyiség egy adott helyén tartózkodott. ${ }^{4}$ Mindezek alapján feltárták azokat az idegsejteket, amelyek az állat topográfiai eszközökkel leírható környezetének adott pontjaira megnövekedett tüzelési aktivitással reagálnak (1.ábra). Ezek a sejtek tehát motoros és vizuális információk integrálásával belső térképen rögzítik az állat pillanatnyi helyét és mozgásának nyomvonalát. A térképezési folyamat csak akkor mutatkozott meg, ha az egyed már megismerte a környezetét, azaz kalibrálta a térképet, kijelölte euklideszi geometria alapján meghatározható fontosabb paramétereket (hosszúság, szélesség, kör vagy téglalap alakú esetleg

\footnotetext{
4 A térsejtek csak haptikus, motoros (a vizsgálatvezető ujjaival az adott pozícióban tartja az állat
} testét) és vizuális ingerek (látja, mi van előtte) együttes jelenléte esetén aktiválódnak. 


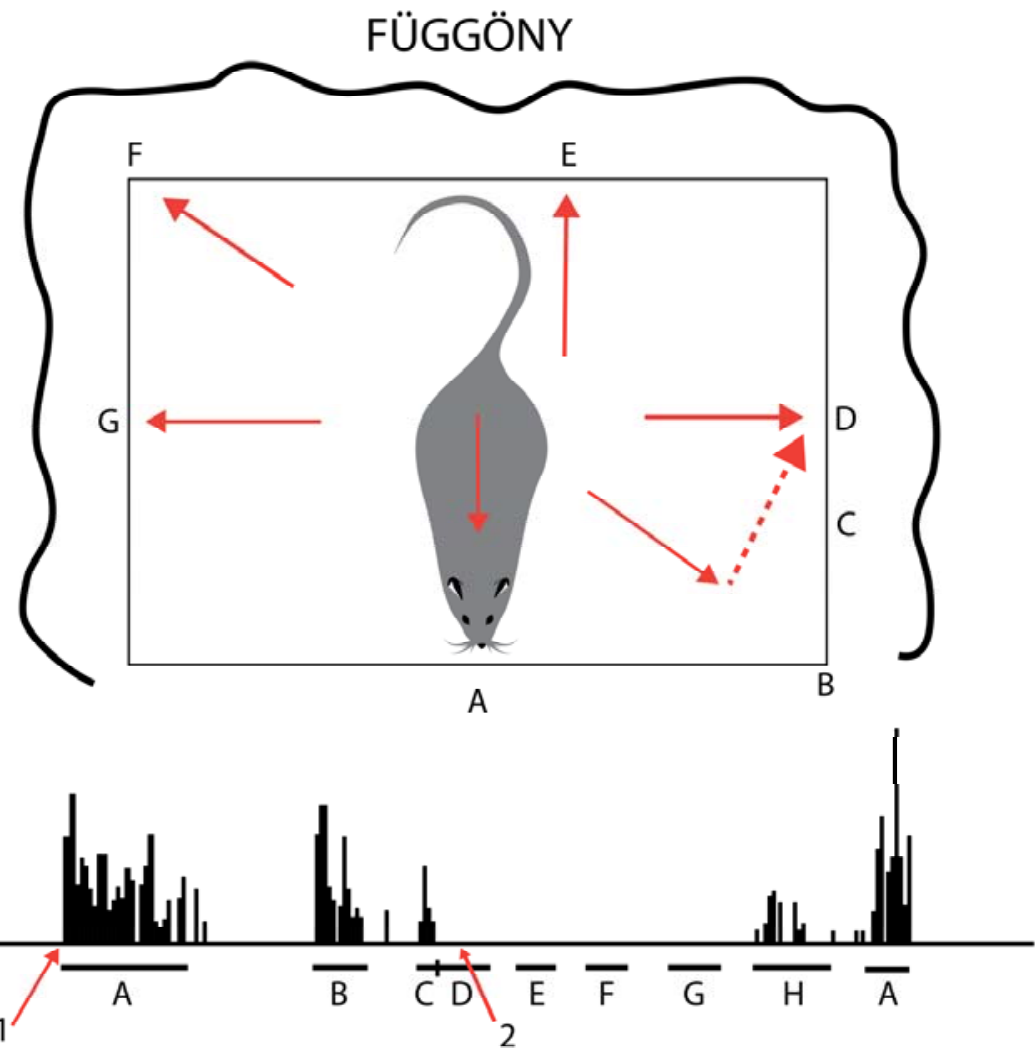

1. ábra. A hippokampusz mint egy területet felderítő térképező rendszer. Szabadon mozgó patkányok egysejtaktivitásával kapcsolatos előzetes adatok (O’KEEFE és DOsTROvsKY, 1971 ábrája nyomán)

amorf). A téri környezet kalibrációjának első szakaszában az egyed hiperaktív, fiziológiai aktivitása magas, keresgél. Ebben az időszakban a tanulási hatékonysága minimális.

Az eredmények összegzése alapján megállapították, hogy a dorzális hippokampusz ${ }^{5}$ téri referenciatérkép-funkciókat is ellát. Az állat testvonalának irányába eső, vele szemben lévő célpontok helyét rögzíti, azok egyéb ingermodalitásaival együtt (illat, padlómintázat, hangok). Következésképpen ismerős környezetben végzett mozgás során az elmozdulás iránya előrevetíti az adott térrész multimodális vázlatát. A helysejtek hippokampusz szövetébe ágyazott elhelyezkedése ugyanakkor nem követi a megfigyelt fizikai környezet topográfiáját. ${ }^{6}$ A helysejtek

${ }^{5}$ Humán megfelelője a hippokampusz poszterior része.

${ }^{6}$ A fentiekben ismertetett, és a későbbiekben más hasonló körülmények között végzett vizsgálatok, amelyek szűk mozgási lehetőséget biztosító, három irányban lefüggönyözött ketrecekben zajlottak, nem adtak lehetőséget a nagyobb kiterjedésű helyeken végzett exploráció és téri reprezentáció érdemi vizsgálatára. 
nem csupán specifikusan reagálnak a környezet kitüntetett pontjaira, de megalapozzák az adott helyre vonatkozó emlékezést, ilyen értelemben tehát a több különböző raktározási formát választó emlékezeti rendszer egyik elemének, elsősorban az epizodikus, kontextuális memória neurális hátterének tekinthető. Az epizódok sajátossága, hogy rövid idejűek. Ennek ellenére térpercepcióban nincsenek jelentős „filmszakadások”. Az epizódokat ugyanis egy default operációs rendszer kognitív térképbe tömöríti, és ezzel tágabb és szűkebb környezetünket kis módosításokkal folyamatosan életben tartja, újraírja. Az anticipáció, azaz a téri kontextus várható megjelenése, (a térkép frissítése) a hippokampusz funkciók temporális artikulációjától függ. ${ }^{7}$ A későbbi vizsgálatok bizonyították, hogy a kognitív térkép, rögzítve a helyzet invariáns mozzanatait, túllép az adott helyhez kötött kontextuson, a környezet általános szabályszerüségeit tartalmazza. Folyamatosan a fizikai törvényeknek megfelelő képet szolgáltat a tárgyak nagyságáról, a gravitáció testekre gyakorolt hatásairól, elmozdulásairól, ösvények, határoló felületek, bennfoglalások törvényszerűségeiről. Következményként az útvonalak és a helyek, a konkrét személyes események emlékét, valamint a személyességtől részben megfosztott absztrakt kognitív térképet közös, de hierarchikusan felépített ego-allocentrikus rendszerbe ágyazza (Burgess, 2006; MEILINGER és VosGERAU, 2010). A nagyobb kiterjedésű, az allocentrikus navigációhoz szükséges disztális navigációs pontokkal ellátott helyek megismerésekor zajló neuropszichológiai folyamatok elemzése az 1980-as években kidolgozott új technikai eszközök ${ }^{8}$ megszületését követően lendült fel, amelyek a kognitív térkép vizsgálatoknak jelentős lökést adtak. Ezeknek a vizsgálatoknak a fó témakörei a navigációs pontok, nyomvonalak, stratégiák, referenciakeretek és térképszerkesztéssel kapcsolatos képességek elemzése volt virtuális és fizikailag valós környezetben. A disztális ingerek szerepének tisztázásáig fogadjuk el a korábbi vizsgálatokból származó kiindulópontot. A szabadon mozgó állat által használt viszonylag szűk vizsgálóketrecben stabil, közvetlenül elérhető térpontok vannak. Ezek a helyek a ketrecben mindig ugyanoda estek, attól függetlenül, hogy a ketrecet áthelyezték, elfordították, azaz megváltoztatták a helyzetét a vizsgálószobán vagy az egyetemi épületen belül. A helysejtek tehát nem általában a tér egy adott pontjára, hanem a térből kimetszett, személyes tapasztalatokkal feltöltött, kis léptékủ geometriai formációk belső elrendezésére adott válasznak tekinthetők.

May-Britt Moser és Edvard Moser a téri tájékozódás és a térpercepció idegrendszeri alapjait, elődeik nyomán, a hippokampuszban igyekeztek feltárni. Feltételezték, hogy a helysejtek nem az a priori fizikai teret, hanem ebben a térben valahol elhelyezkedő ingerforrásokat definiálnak, azaz le vannak horgonyozva valahol, az állat által bejárt epizódok geometriai rendszerében, de nem tudni, hogy is helyezkednek el ezek a pontok más terekkel való viszonylatokban. A tér ugyanis navigációs pontokon keresztül definiálható tárgyak, személyek, élmények egy-

\footnotetext{
7 Az e helyen bemutatott vizsgálat a térkép frissítésének idői komponenseinek elemzésével még nem foglakozik. Ezek ismertetése BUZSÁKI (2011) és FREUND (1996) munkáiban megtalálhatók.

8 Standardizált vizsgálati környezetet biztosító Morris-féle vizes cilinder alakú útvesztő (MORRIS, 1984) és a computer által létrehozott virtuális valóságok (NADEL, THOMAS, LAURANCE, SKELTON, TAL és JACOBS, 1998).
} 
máshoz viszonyított vektoriális rendszerében értelmezhető. Ez a megközelítés a korábbi álláspontokkal megegyező, amely azt feltételezte, hogy téri navigáció során két egymásra épülő referenciarendszer irányítja a tájékozódást. Az egyikben a navigáló testének aktivitása (nézésirány, a test frontális felületének elfordulásai, fej-, test- és végtagmozgások, a test középvonalától való elmozdulása), és ezek összehangolásából adódó, a testséma által meghatározható navigáció, ${ }^{9}$ ezt nevezzük egocentrikus referenciakeretnek. Ezzel szemben az allocentrikus reprezentáció a test aktuális pozíciójától független a priori téri elrendezésben szemlélhető tárgyak egymáshoz viszonyított rendszere alapján határozhatók meg. A térpontok, amelyben egyes térhatároló elemek, mint például a szoba sarka vagy rövidebb oldala, tárgyként definiálhatók. Tehát a személy által használt önálló, kihasított szűkebb tér geometriája lezárja ugyan a teret, de az elzárt tereket vagy zónákat az allocentrikus reprezentáció összehangolja egymással. Az egocentrikus terek zónái megkülönböztető idői kóddal kapcsolódnak egymásba. A tér meghatározó elemei globálisak, égtájaktól függők vagy határtalanok, mint például a világűr. A figyelem előterébe állított referenciapontok természetesen itt is fellelhetők, de a célpontok meghatározása nem a megfigyelő, hanem a megfigyelt objektumhoz való vektoriális viszony alapján történik. ${ }^{10}$ A kognitív térkép teória szerint az egymást követő útvonal-fordulópontok által kijelölt egocentrikus reprezentáció, szinte melléktermékként, az adott terület térképét adja meg. A motivált és az esetek többségében automatizmusokra épített egocentrikus mozgásvezérlés elsősorban a parietális lebeny poszterior részéhez, és ezen keresztül a dorzális vizuális idegpályákhoz köthető, míg a térképszerkesztés és a térkép alapú navigáció a hippokampusz és az azt körülvevő struktúrák (parahippokampális kortex) felségterületén maradva, a ventrális köteg ${ }^{11}$ részeként működik. Az allocentrikus tér, hasonlóan a tárgyakhoz, változatlan marad akkor is, ha a személy elmozdul, más perspektívából vizsgálódik, lényegében jelentéstani konstanciával rendelkezik. Ezzel szemben, ha a személy helyet vagy nézőpontot változtat, az egocentrikus tér megváltozik. Ha egy szobába belépve az ajtótól eltávolodunk, a szemben lévő oldal bútorzata közelebb kerül hozzánk. Ugyanez a mozgás allocentrikus reprezentációs keretben semmilyen lényeges változást nem okoz. Ilyen értelemben tehát az allocentrikus reprezentációra támaszkodó kérdés felvetésekor azt kérdezzük „Mi van ott?”, az egocentrikus reprezentáció esetén azonban kérdés így szól, „Hol van az?” A két referenciarendszer kölcsönösen segíti egymást. A térképet nyújtó „madártávlat” és a személyes nézőpont, azaz a harmadik és az első személyủ perspektíva integrációja a megfelelő orientáció alapfeltétele (2. ábra).

PET-, strukturális MRI- és $f$ MRI-vizsgálatok felhívják a figyelmet arra, hogy a navigációs feladatok különböző elemei, navigációs tárgyak, útvonalak, stratégiák, referenciakeret megválasztása, a kereső mozgás sebessége, a feladat típusa és az általa igényelt memória szerint változik a téri feladatok során azonosítható neurá-

\footnotetext{
9 Nyelvi kifejezése tekintetében intrinzikus, az adott személy tulajdonságához tartozó jellemző, mint eleje, hátoldala, jobb vagy bal fele).

10 Lingvisztikai értelmezésben deiktikus.

11 A ventrális köteg elsősorban a tárgyak alaki tulajdonságainak elemzése révén a tárgyfelismerésben játszik kiemelkedő szerepet, tehát a „mi ez” rendszer alapeleme.
} 


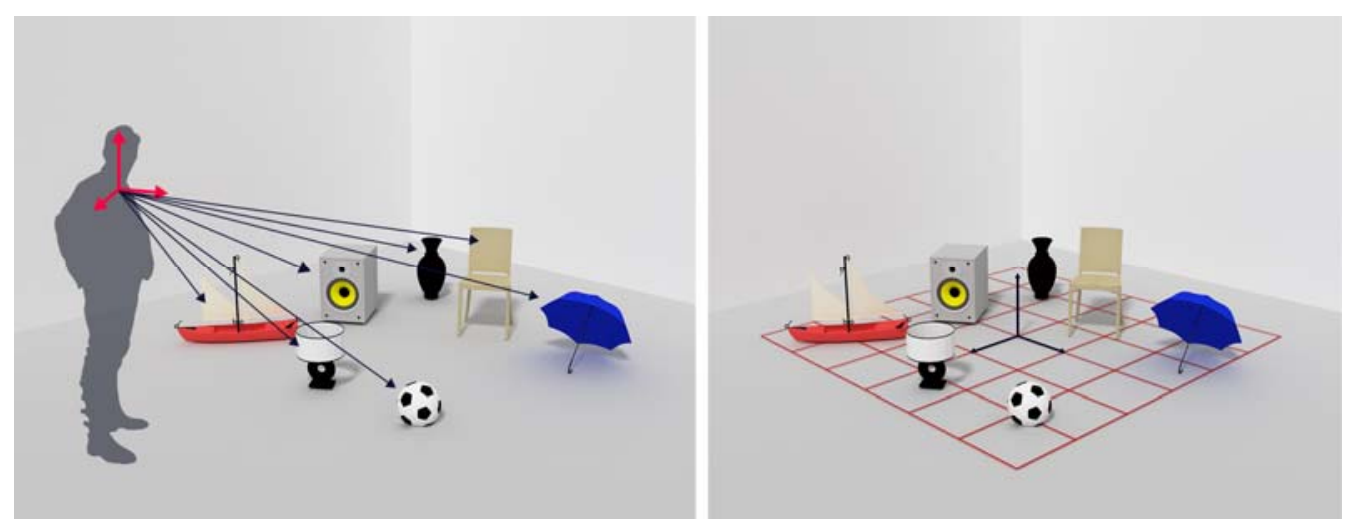

2. ábra. Az egocentrikus és allocentrikus téri reprezentáció megkülönböztető sémája (MEILINGER és VOSGERAU, 2010 nyomán)

lis hálózat összetétele. A hippokampusz mellett, a téri memóriában a parahippokampális kortex (viszonylag egyszerủ geometria elrendezések, szoba falai) a formák felismerésében, az útvonalon való haladás sebességében a nukleusz kaudátusz (MAGUiRe, Frackowiak és FriTH, 1998), a navigáció pontosságában pedig a jobb hippokampusz mellett az inferior parietális lebeny aktivitása játszik jelentős szerepet (Maguire és mtsai, 2000; Burgess, Maguire és O’Keefe, 2002). Computer által létrehozott virtuális realitásban végzett navigáció során mások is rámutattak arra, hogy az útvonalkövetés során szerzett epizódok, amennyiben a tanulási feladat ezt igényli, összességében véve háttérbe szorítják az egocentrikus proximális helyzetű navigációs pontok szerepét, és disztális helyzetű térképelvű navigációt követve érik el a kitűzött célt (NADEL, ThOMAS, LAURANCE, SkELTON, TAL és JACOBS, 1998), a térkép alapú tájékozódás során a jobb hippokampusz szerepe kiemelkedőnek mutatkozott (ThOMAS, Hsu, LAURANCE, NADEl és JACOBS, 2001).

\section{EGOCENTRIKUS TÉRI REPREZENTÁCIÓ}

Az egocentrikus reprezentációs rendszer az okkulomotoros, fejforgató, testtartási rendszer - alapvetően a retina, a proprioceptív és vesztibuláris inputok - egysége alapján ágyazza kognitív térbe a rendelkezésre álló információkat. Az egocentrikus perceptuális automatizmusok nem csak az exteroceptív ingerek rendezésének elsődleges eszközei, de a válasz kivitelezés és előkészítés összetett mozgási automatizmusának harmóniájáról is gondoskodik. A megfigyelő szempontjából tekintve, a cél elérése során jobbára csak a célpontot kell definiálni az affordanciák alapján, a cselekedet többé-kevésbé automatikusan lezajlik. Ami fent van, azért felfelé, ami lent, azért lefelé kell nyúlni. A szemlélőtől független megfigyelési pont választása esetén azonban az egocentrikus reprezentációnak inkább hátteret biztosító szere- 
pe van. Mindezek rámutatnak arra, hogy a téri keretezés személy- vagy tárgyfüggő módja egységet képez ugyan, de mégis különböző eredményre vezet. Felvethető a kérdés, hogy az előtér-háttér konfliktusa esetén milyen módon egyenlítődnek ki a két különböző látásmódból származó relatív téri és idői különbségek ${ }^{12}$. Kiemelt jelentősége van tehát az egocentrikus-allocentrikus referenciaképzés és a referenciaváltási folyamat (BURGESS, 2006) ismeretének. A tevékenység megfigyelőtől való távolsága alapján alkotott csoportosításokat, a működési lehetőségüket biztosító neurális aktivitáshálózatokkal együtt, kétpólusú referenciakeretbe, mint metarendszerbe, illeszthetjük, melyek között mind az átfedés, mind az integrált együttműködés és a paralel információfeldolgozás, természetes állapot. A két rendszer alkalmi vagy esetenként végzetes tájékozódási zavarokat okozó disszociációja azonban egyértelműen mutatja, hogy ez a kollaboráció fokozott tudati erőfeszítést igényel, jelentős figyelmi erőforrásokat köt le, és érzelmi hatásoknak nagymértékben kiszolgáltatott (KÁLLAI, 2013).

\section{ALLOCENTRIKUS TÉRI REPREZENTÁCIÓ}

Az allocentrikus reprezentáció, lényegét tekintve, a disztális pozícióban lévő tárgyak közti téri viszonylatok megszerkesztését tartalmazza, egy rugalmas mentális térkép formájában veszi fel a „mi és hol” adatokat. Az allocentrikus tér központjában nem a megfigyelő, hanem a tér mentális komputációval létrehozott „súlypontja” áll (lásd centroid modell, O’KeEFE, 1991). Mivel a személy pillanatnyi pozíciója az allocentrikus térben nem lényeges, ezért az allocentrikus tér struktúrája a tárgy vagy a megfigyelő térben végzett mozgása esetén is változatlan marad. Az allocentrikus tér tartalma a tájékozódási pontok felé vezető útvonalakból, a különböző tárgyak közötti viszonyokból, irányvektorok rendszeréből (távolság, hajlásszög), megközelítési vagy elkerülési stratégiákból épül fel (O’KEEFE és NADEL, 1978). Az említett stratégiák és a helytanulás vizsgálatának egyik legmegbízhatóbb módszertani eszköze a Morris-típusú Vizes Útvesztő" ${ }^{13}$ (MORRIs, 1984), amely térben, időben pontos automatikus adatrögzítési lehetőséget biztosít valós és virtuális térben, állatok és humán alanyok által végzett navigáció elemzéséhez.

Az allo- és egocentrikus reprezentáció fejlődésmenete különböző (O’KeEFE és NADEL, 1978; PAILLARD, 1991). Az eltérő működésmód ugyanakkor nem jelenti a téri reprezentációs formák szeparálódását. Ezt a tényt erősíti meg az egocentrikus és allocentrikus reprezentáció párhuzamos rendszermodellje (BURGESS, 2006), amelynek értelmében a téri komponensek fluktuálnak, átmeneti időre jelennek meg. Egyrészt létrehozzák a szelf és tárgy viszonyrendszerét (egocentrikus) a hozzá kapcsolódó akciók sokaságával, másrészt a hosszabb távon maradandóbb tár-

\footnotetext{
12 Számos megváltozott testélmény- és testtudat-illúzió jelzi a két referenciarendszer összeillesztésének kritikus pontjait. Ezeket a jelenségeket a multimodális integráció manipulációját biztosító, computer által létrehozott valóságok és testrészillúzió-vizsgálatok eredményei igazolják. Lásd részletesebben Petkova, Björnsdotter, Gentile, Jonsson, Li és Ehrsson, 2011; KÁllai és mtsai, 2015 munkáit.

13 Részletes ismertetését lásd később, a 755. oldalon.
} 
gyak és a környezet közti (allocentrikus) referenciakeretet biztosítják. E tranziens folyamat eredményeként a téri reprezentáció keretei, az előtér és a háttér, dinamikusan váltják egymást.

\section{A KOGNITÍV TÉRKÉP ÉS AZ EGOCENTRIKUS TÉR ALAPÚ REPREZENTÁCIÓK INTEGRÁCIÓJA}

A kognitív térkép előrevetíti a törzs és a fej elmozdulásakor várható vesztibuláris, vizuális szenzomotoros bemeneteket, a mozgás befejezésének végállapotát, ellenőrzi és kiszámítja az állandó tárgyak koordinátáit (JACOBS és SCHENK, 2003). Minden felvett információ tartalmaz a személy aktuális állapotára vonatkozó mozgásos, proprioceptív elemeket, amely pozicionális szignálok révén folyamatosan módosítja a feldolgozás referenciarendszerét. Ennek következtében a kognitív séma minden pillanatban az észlelőt és az észlelő környezetét egységes egészként regisztrálja. Azaz a kognitív térképnek realitásgeneráló funkciója van. Az én és a világ a kognitív sémában együtt van jelen. Az említett két alapvető téri referenciakeret a személy saját helyzetének és a tárgyak egymáshoz viszonyított helyzetének kiindulópontja, hiszen az egyik „én” vonatkozású a másik pedig „nem én” vonatkozású. Következésképpen az „Én” és a „Másik” különbsége referenciakeret-definíció alapján is megjeleníthető.

A téri tájékozódás referencia-rendszere kétkarú mérlegként fogható fel. Egyik serpenyőjében az egocentrikus, másikban az allocentrikus reprezentációk helyezkednek el. Az előbbi elsősorban a parietális kortikális területekhez, az utóbbi inkább a hippokampusz funkciókhoz kötődik. Szorongató események következményeként keletkező stresszhatásokra a hippokampusz funkcióinak egy része gátlás alá kerül (JACOBS és NADEL, 1985). Következményként a mérleg nyelve az egocentrikus reprezentációk aktivációja felé billen, de ez esetben a kontextuális térképező funkciók hiánya miatt a történéseket kiváltó ingerek nem ágyazódnak be a kontextus tágabb rendszerébe, dekontextualizálódnak. Ennek következménye az intenzív szorongásokkal küzdő személyek, elsősorban a pánik agorafóbiás betegek tüneti viselkedésén egyértelműen megmutatkozik. Az egyed, elveszítve a harmadik személyű perspektíva nézőpontjából érkező információkat, egyedül marad procedurális automatizmusaival, nincs hatalma önmaga felett (KÁLLAI, SzABÓ, VARGA, Molnár és KóczÁn, 1995; JACOBS és NADEL, 1999). E megközelítésben teoretikus értelemben felvethető az a kérdés, hogy az előtér-háttér referenciaváltások időszakában megjelenhet-e a szelf egocentrikus és allocentrikus keretben egyszerre? Úgy tűnik, szkizofrénia, epilepsziás aura, az anguláris girusz transzkraniális magnetikus stimulációja, sajáttest-élményt mozgósító illúziók során megjelenő élmények nem tesznek értelmetlenné ilyen irányú kérdésfelvetést. A fő kérdés továbbra is az, mi biztosítja a változó reprezentációk ellenére a térpercepció és a térélmény viszonylagos stabilitását. 


\section{A rácssejtek}

O’Keefe laboratóriumában szerzett egysejt-implantációs, valamint R. Morris laboratóriumában szerzett helytanulási vizsgálatok tapasztalatai alapján M-B. Moser és E. Moser a Trondheimi Egyetem interdiszciplináris kutatólaboratóriumában a helysejtek extrahippokampális be- és kimeneteit vizsgálta. Megállapították, hogy az entorhinális kéregben hasonló tüzelési rátával rendelkező neuronok vannak, mint a hippokampuszban. Ezek a sejtek azonban nemcsak a tér egy meghatározott, az állat által kiválasztott helyén, hanem attól függetlenül is működésbe lépnek. Miközben az állat a helyiséget explorálja, az entorhinális kérgében lévő sejtek aktivitásmintázatukkal szinte lemásolták a helyiség alaprajzát. Az idegszövet egysejtaktivitás-mintázata azonban nem volt egységes, bizonyos nagyobb felbontású gócpontok, zónák köré rendeződött. A zónák elrendezése hatszög alakú geometriai formát öltött (3. ábra). A helyiség felderítése során felvett idegsejtmintázat

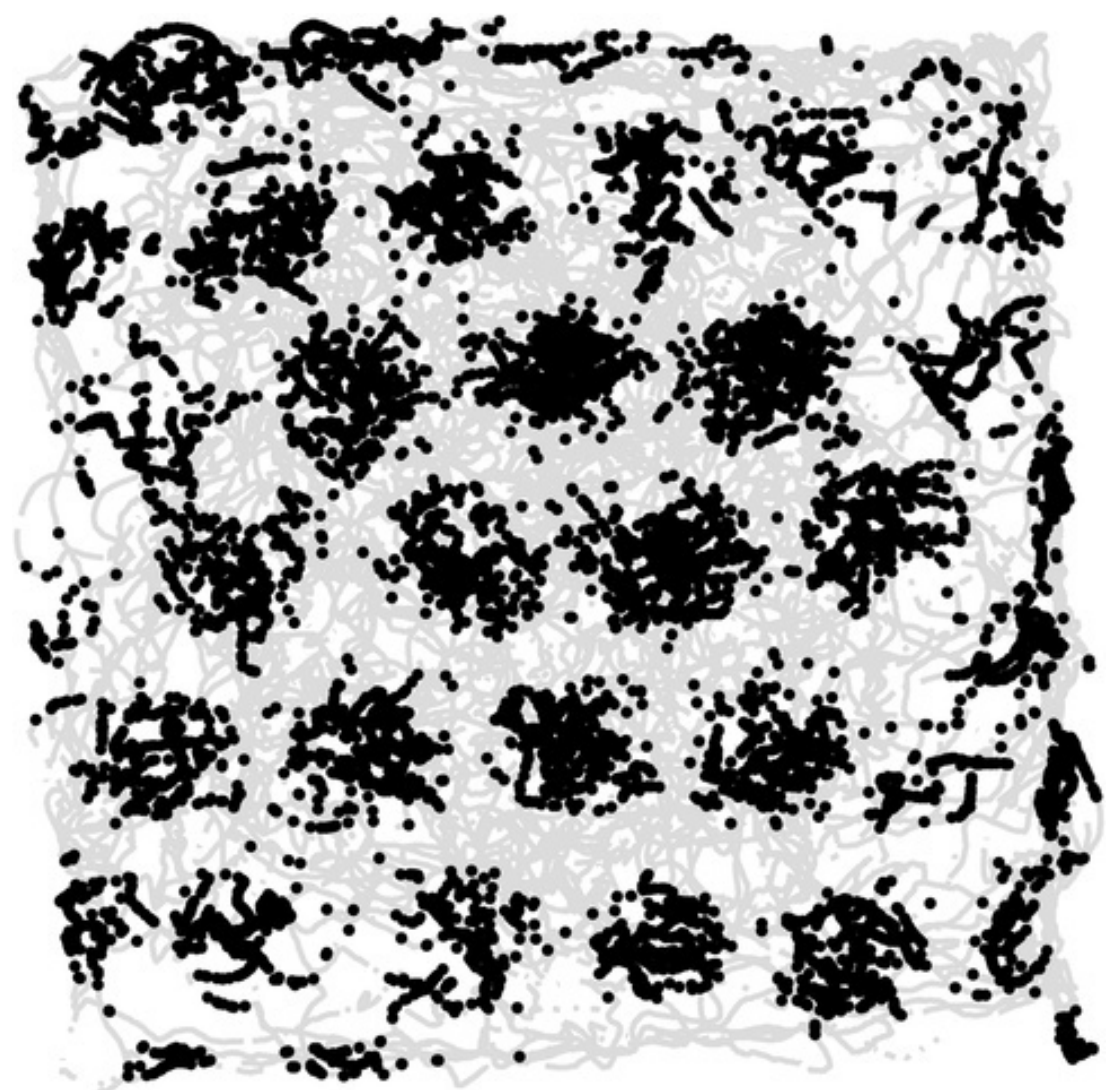

3. ábra. Hatszögű „Halma”-hálózatba rendeződött egysejt-tüzelési mintázat, amely lefedi az egyed által felderített teljes területet. Mértani elrendezése alapján lehetőséget ad a hely euklideszi paramétereinek rögzítésére, és az esetleges transzformációk elvégzésére. 
tehát az euklideszi geometria elveit követő olyan egyenlő oldalú háromszögekbe rendeződött, amelyek csúcspontjai egy hatszög szerkezetének központi elemét alkotják. A fizikai tér háromszögekben, hatszögekben és további geometriai rendben kombinálható aktivitásmintázata így megnyitotta az utat a szemlélőtől független téri alakzatok észlelésére, illetve neurális transzformációjának matematikai elemzése felé. Az említett rácsszerű aktivitásmintázat sajátossága, hogy a kódoló felület a felderítés során bejárt hasonló felépítésű helyekkel való találkozásakor újabb exploráció nélkül aktiválódik. A fix mintázat artikulációja az entorhinális kortex felületén a ventrális iránytól a dorzális irány felé növekszik. Tehát a hatszögü ${ }^{14}$ kódoló felület olyan univerzális, faltól falig terjedő sablonba rendezett rácsos szerkezet, amelyet az állat a hely kalibrálásával keltett életre. A rácssejtek ugyanakkor a hippokampuszban nem találhatók meg, de a rács és a hippokampális helysejtek összeköttetésben vannak egymással. A téri tájékozódásban szerepet játszó további téri sejtcsoportokat azonosítottak, a test pillanatnyi helyzetétől független fejirány-sejteket, valamint a határoló felületekre reagáló sejteket, amelyek szintén az entorhinális kortex területén halmozódnak ${ }^{15}$ (LEUTGEB, Leutgeb, Barnes, Moser, McNaughton és Moser, 2005; Zhang és mtsai, 2013). A téri alaprajzot leképező rácsrendszeren belül kiemelkedő aktivitást azok a sejtek mutatnak, amelyek a hippokampális helysejtek felől erre ösztönzést kapnak, a helysejtek a rácsrendszeren belül lokalizálják önmagukat (BONNEvIE és mtsai, 2013).

Az entorhinális kortexben az adott terület explorációja (lokomóció, fejfordítás, határoló felületek, taktilis és olfaktoros manipulációja) egy koordináta-rendszert hoz létre, amely centroidok, irányszögek és vektorok rendszerének felhasználásával kódolja le a figyelem előterébe került terület paramétereit. A kódolás módja nézőponttól független, de az entorhinális rácssejtek és a hippokampális helysejtek, valamint a fejforgatásra, a határoló felületekkel való találkozásra érzékeny sejtek együttműködése alapján alkalmas mind az egocentrikus, mind az allocentrikus reprezentációk felépítésére (FYHN, MOLDEN, WitTER, MOSER és MOSER, 2004; COUEY és mtsai, 2013). Ezek a változást követő epizódok hordozzák az emlékek lokális kontextusát. A hippokampusz és az entorhinal kortex együtt, téri információkat kódoló és integráló szervrendszer, amelynek receptorfelülete helysejtekre, fejpozíciósejtekre, határsejtekre és rácssejtekre épül. Nemcsak a környezeti navigációs szignálokat veszi fel, hanem a receptorfelület folyamatosan frissíti önmagát. A hippokampusz ebben a struktúrában vezető szerepet lát el, ha a hippokampuszt biokémiai blokád alá helyezik, a rácssejtek funkciója megváltozik. Helyváltoztatást nem kódolnak, csak fejforgatási irányt (BONNEviE és mtsai, 2013). Azaz a rácssejtekben az egocentrikus funkciók kerülnek előtérbe.

14 Halma, kínai hatszereplős sakkjáték táblájának mintázatához hasonló.

15 Tulajdonképpen azon az agyterületen, amelyen az Alzheimer-betegség első idegrendszeri tünetei megjelennek. 


\section{MORRIS-TÍPUSÚ ÚTVESZTŐ MODELL ALKALMAZÁSA HUMÁN HELYTANULÁSI VIZSGÁLATAINKBAN, KLINIKAI ÉS EGÉSZSÉGES POPULÁCIÓVAL, VALÓS ÉS VIRTUÁLIS TÉRBEN}

Az összefoglaló záró fejezetében a humán navigáció szorongással összefüggő elemeivel kapcsolatos vizsgálataink közül mutatok be néhányat, amelyek többségét a Morris-féle útvesztő paradigma nyomán készítettük, computer által létrehozott virtuális valóságban végeztük, más részük in vivo, a mindennapokban rendelkezésre álló útvesztőkben zajlott. Humán klinikai esetek és állatokkal, főleg rágcsálókkal végzett helytanulási vizsgálatok során többszörös emlékezeti raktározást és ennek megfelelően előtér-háttér hatásokat vizsgáló módszereket írtak le, amelyek közül napjainkig az egyik legnépszerúbb az R. Morris által megszerkesztett Morris-típusú vizes medence feladat (Morris water maze; MORRIS, 1984). A rágcsálók részére kidolgozott tájékozódási feladat lényege az alábbi: nem átlátszó vizű, kerek, aréna alakú medence vízszintjéhez közel, de már nem látható módon, a vízből menekülni törekvő állat számára egy fix helyzetű dobogót létesítettek. A medence köré épített falazatra, égtáj szerint, navigációs jelzéseket helyeztek el.

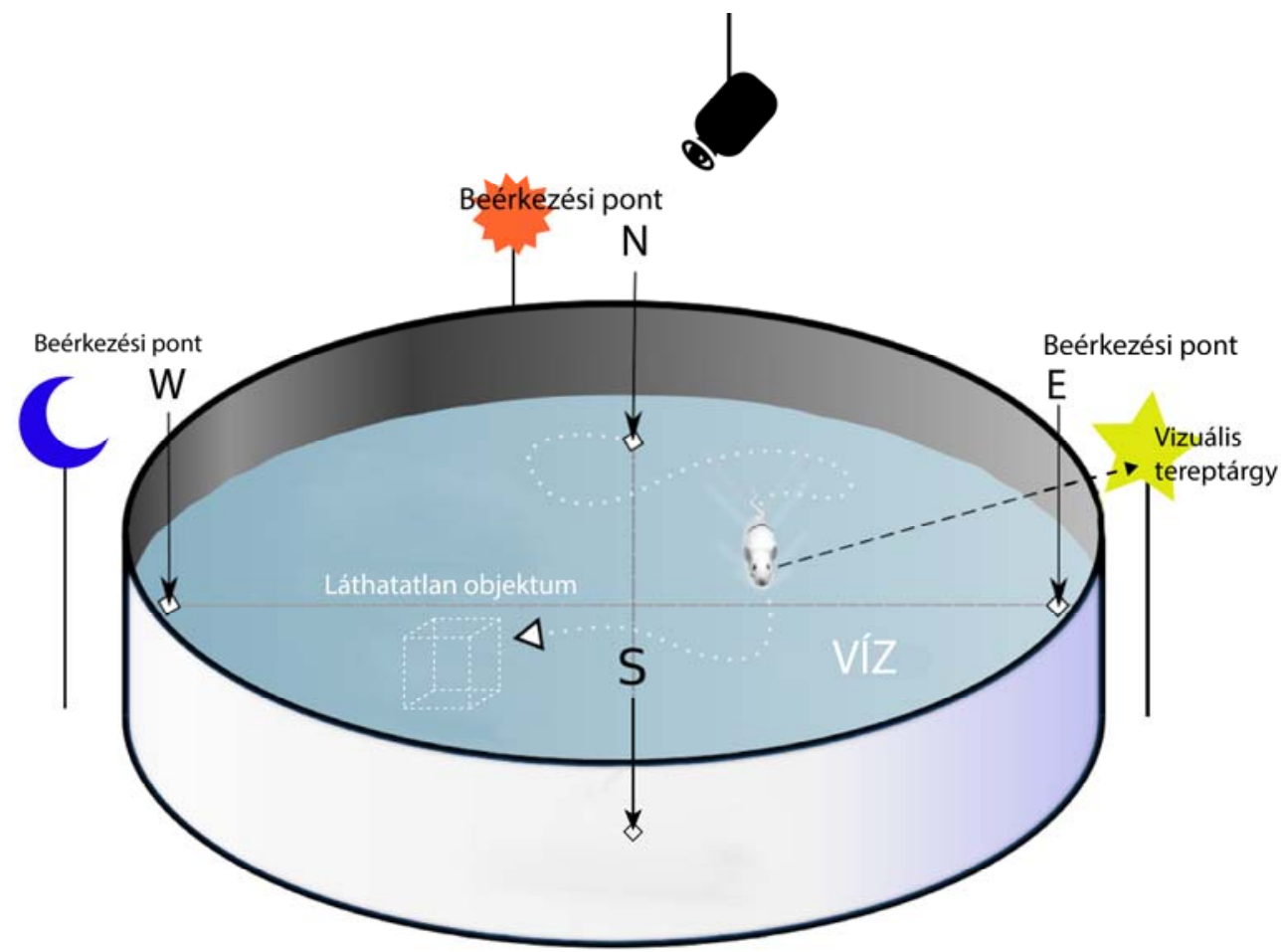

4. ábra. Morris-típusú vizes útvesztő vázlatrajza, amelyben a tesztaréna környezetében lévő disztális területeket szabadon meg lehet változtatni, ezzel vizsgálható az állat keresési stratégiája különböző feltételek között. 
Ezek segítették a menekülést jelentő dobogó helyének gyors megtanulását. A feladat végrehajtása gyorsan haladt, amikor az állatot az aréna ugyanazon helyén tették a medencébe. Hamar megtanulta, hogy az indulást követően milyen fokban kell jobbra vagy balra fordulnia, és az aréna falától milyen távolságban találja meg a platformot. Egocentrikus pozícióból kiinduló útvonalkövető tanulási stratégiát használt. Ez a stratégia nem vezetett eredményre, ha az aréna különböző pontjain helyezték az állatot a vízbe. Ebben az esetben ugyanis nem a kiindulópont és a célpont közötti útvonal követése, hanem a célpont disztális navigációs pontok rendszerében elfoglalt helyének emlékezeti rögzítése kínálta a megfelelő megoldást. Allocentrikus térkép alapú stratégiát kellett alkalmaznia. A vizsgálati elrendezés, a disztális térben elhelyezett navigációs pontok módosításán és a kiindulópontok szisztematikus változtatásán keresztül tette lehetővé a téri emlékezet különböző összetevőinek együttes vizsgálatát (4. ábra). Ebben a környezetben számos genetikusan módosított fejlődésmenetű, hippokampusz-sértett, gyógyszerhatás alatt álló, egysejt-potenciált elvezető beépített elektródával szabadon mozgó állat vizsgálatára nyílott lehetőség. Megállapították, hogy a dorzális hippokampusz, a szubikulum, a mediális frontális kortex sérülése jelentős zavarokat okoz a helytanulásban (MORRIS, 1984).

Amint már volt róla szó, a helytanulás és a helysejtek mechanizmusainak leírásában mérföldkőnek számított az R. Morris által kidolgozott, egyszerűen variálható, de a helyváltoztató mozgást automatikusan rögzíthető képet szolgáltató Morristípusú vizes medence feladat (Morris Type Wather Maze, MWM; MORRIS, 1984; Noldus Technology Etho Vision Video Pro Tracking System, 2001; MAKÁNy és KÁLLAI, 2004). A Morris-típusú útvesztő bizonyos módosításokkal stabil és egyszerủen alakítható feltételeket kínál a humán vizsgálatok számára is. A virtuális valóság szoftverek megszületésével lehetővé vált a MWM modell humán vizsgálatban való felhasználása. E tárgyban talán ez első NADEL és munkatársai (1998) Computer Generated Virtual Arena (CGArena) programja volt (5. ábra), amelyet hamarosan számos hasonló vagy összetettebb városi környezetet modelláló eszköz megjelenése követett.

Laboratóriumunk a Nadel-munkacsoport meghívására 1998-ban kapcsolódott be a virtuális valóságban végzett helytanulási vizsgálatokba. Egy nagyobb projekt keretei között a humán helytanulás és a szorongás viszonyának elemzését vállaltuk. Klinikai pszichoterápiás tevékenységünk során azt tapasztaltuk, hogy a szorongás megzavarja az egocentrikus-allocentrikus referenciarendszer összekapcsolódását. Ez az előtér-háttér referenciaváltási nehézség, korábbi hipotézisekkel szemben (JACOBS és NADEL, 1985), elsősorban pániktól és agorafóbiától szenvedő személyek esetén volt feltűnő. Klinikai esetek elemzése során arra a következtetésre jutottunk, hogy az életvezetést súlyosan akadályozó agorafóbiának egyik kiemelkedő kóroka az eddig a klinikai gyakorlatban kevésbé ismert téri kontextuális és epizodikus információk feldolgozásának zavara lehet. ${ }^{16}$

16 A szorongás spektrumába tartozó személyekkel folytatott kognitív és viselkedésterápiás klinikai tapasztalataink részletes kifejtésére e helyen nem vállalkozom. Ezek összefoglalója megtalálható KÁLLAI (2004) A téri tájékozódás és a szorongás című monográfiában. 


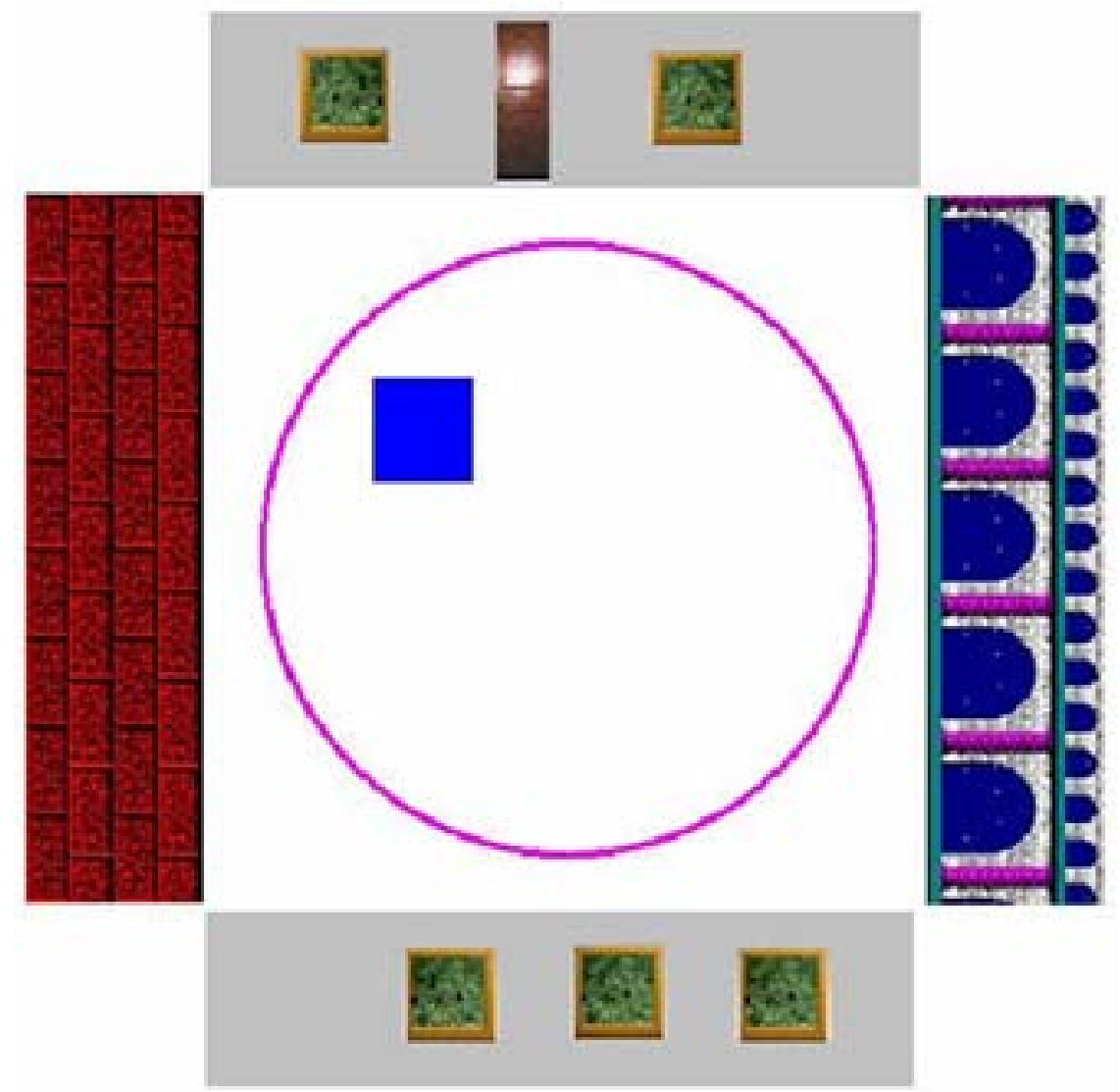

5. ábra. Computer által létrehozott valóságvizsgálat, a CGArena kétdimenziós vázlata

A magas falú arénán belül elhelyezett négyzet, a menekülési platform csak akkor látható, ha a szabadon exploráló személy a joystickkel véletlenül rátalál. Ezt követően megjegyzi a disztális navigációs tárgyak aktuális konfigurációját, hogy a rejtett platformot a későbbi próbák során eredményesebben tudja felderíteni.

Vizsgálataink során az alábbi kérdésekre kerestük a válaszokat: 1. Valós és computer által létrehozott virtuális térben végzett navigáció során mutatkozik-e allocentrikus és egocentrikus referenciahasználati különbség szorongó és nem szorongó személyek téri reprezentációjában? 2. Amennyiben mutatkozik ilyen különbség, a szorongás milyen mechanizmusokon keresztül befolyásolja a téri reprezentáció kialakításának módozatait? 3. A navigáció során regisztrált stratégiák eltérnek-e egymástól, és ha igen, milyen kognitív műveletek tükröződnek a navigáció különböző változataiban? 4. Az eredmények felhasználhatók-e a klinikai gyakorlatban, és felvethető-e valamilyen kognitív idegtudományi szempontból értelmezhető alapzavar, amelynek ismerete segít a tartós eredményt hozó terápiás módszerek fejlesztésében? 


\section{Allocentrikus és egocentrikus referenciaképzés klinikai vizsgálata valós} és computer által létrehozott virtuális térben

A téri információ és a szorongás tanulás-lélektani elemzése alapján JACOBs és NADEL (1985) felvetette, hogy a szimplex fóbiák és a traumatikus eseményeket követő stressz tünetei részben az epizodikus emlékezet kontextusának elvesztésére utalnak. A patológia elsősorban a stresszhormonokra érzékeny hippokampusz sejtjeiben bekövetkező folyamatokra vezethető vissza. A fenti elmélet poszttraumatikus betegségekre vonatkozó érvényességét számos adat megerősíti, de a szimplex fóbiák esetében az adatok száma elenyésző. Vizsgálataink hívták fel a figyelmet arra, hogy az említett dekontextualizáló és a téri tájékozódási képességre jelentős hatást gyakorló kognitív alapzavar a pániktól és agorafóbiától szenvedő személyek kognitív tevékenységének eredményeként elkerülő vagy fejvesztve menekülő viselkedéshez vezet. Pánikbetegek, generalizáltan szorongó és egészséges kontrollszemélyek alagsori útvesztőben mutatott tájékozódási teljesítménye alapján megállapítottuk, hogy az indulópont és a célba érkezés közötti út során kialakított emlékek alapján megrajzolt útvonalat és az épület alaprajzának térképét a pánikbetegek nem tudták pontosan felidézni és megrajzolni. Sokszor eltévedtek a cél felé vezető útjuk során. A generalizált szorongók és a kontrollszemélyek ugyanakkor megfelelő teljesítményt nyújtottak. A pánikbetegek, a navigációs tárgyakról adott beszámoló során, a kontrollszemélyekhez viszonyítva nem mutattak jelentős hátrányokat (1. táblázat). Tehát a pániktól és agorafóbiától szenvedők emlékeztek ugyan a fontos navigációs tárgyakra, de nem tudták a navigációt segítő téri struktúrába beilleszteni azokat. Hiányzott a cselekvési kontextusba való beágyazottságuk, emlékezeti folyamataikban a dekontextualizáció jelei mutatkoztak (KÁLLAI és mtsai, 2005).

1. táblázat. Téri tanulás és emlékezet a labirintusséta közben

\begin{tabular}{|c|c|c|c|c|}
\hline Feladat & Csoportok & Átlag & F-érték & Szignifikancia \\
\hline \multirow{3}{*}{ Térképrajzolás } & 1. PA & $-0,31 \quad(0,6)$ & \multirow{3}{*}{$F=3,05$} & \multirow{3}{*}{$\begin{array}{l}p<0,05^{*} \\
2-1^{*}\end{array}$} \\
\hline & 2. GSZ & $0,40 \quad(0,9)$ & & \\
\hline & $3 . \mathrm{K}$ & $-0,08 \quad(0,8)$ & & \\
\hline \multirow{3}{*}{ Navigációs pont } & 1. $\mathrm{PA}$ & $\begin{array}{ll}3,8 \quad(1,3) \\
\end{array}$ & \multirow{3}{*}{$\mathrm{F}=1,38$} & \multirow{3}{*}{ n. s. } \\
\hline & 2. GSZ & $(2,1)$ & & \\
\hline & 3. K & $4,4 \quad(1,5)$ & & \\
\hline \multirow{3}{*}{ Útvonalkövetés } & 1. PA & $88,09(7,8)$ & \multirow{3}{*}{$\mathrm{F}=11,12$} & \multirow{3}{*}{$\begin{array}{l}p<0,01^{* *} \\
2-3^{*}, 1-3^{*} \\
1-2^{*}\end{array}$} \\
\hline & 2. GSZ & $89,04 \quad(5,4)$ & & \\
\hline & $3 . \mathrm{K}$ & $96,81 \quad(5,5)$ & & \\
\hline
\end{tabular}

*: $p<0,05 ;{ }^{* *}: p<0,01$

A labirintussétát követő interjúban a személyek beszámoltak a navigációt segítő tájékozódási pontokról, megrajzolták az alagsor térképét és a haladási útvonalukat. A személyek visszafelé vezető útjáról készült videofelvételek segítségével határoztuk meg az útvonal-követési hibákat, az eltévedések mértékét (PA: pánik és agorafóbia; GSZ: generalizált szorongás; K: kontroll). 
Extraterritoriális térben végzett explorációs mozdulatok szerepe a pániktól és agorafóbiától szenvedök elkerülö viselkedésében

További vizsgálataink során egy újabb csoport közreműködésével, hasonló tünetekkel rendelkező betegekkel, a korábbival megegyező labirintusban végeztünk egy vizsgálatot. ${ }^{17}$ A betegek egy csoportjának komoly kihívást jelentő labirintusban, az alkalmazott navigációs stratégiákra és az explorációs viselkedés elemeire voltunk kíváncsiak. Úgy gondoltuk, hogy az agorafóbiás viselkedésnek több olyan komponense van, amelyek a törzsfejlődés során, humán egyedek vonatkozásában csak kis mértékben változtak, automatizáltak, és ezek felszínre hozása és módosítása elősegítheti a regisztrált kognitív alapzavarok korrekcióját. A nyílt vagy zárt, kevés tájékozódási lehetőséget kínáló helyzet minden emlős, még a ragadozók számára is, kockázatokat rejt, különösen akkor (mint például agorafóbia esetén),

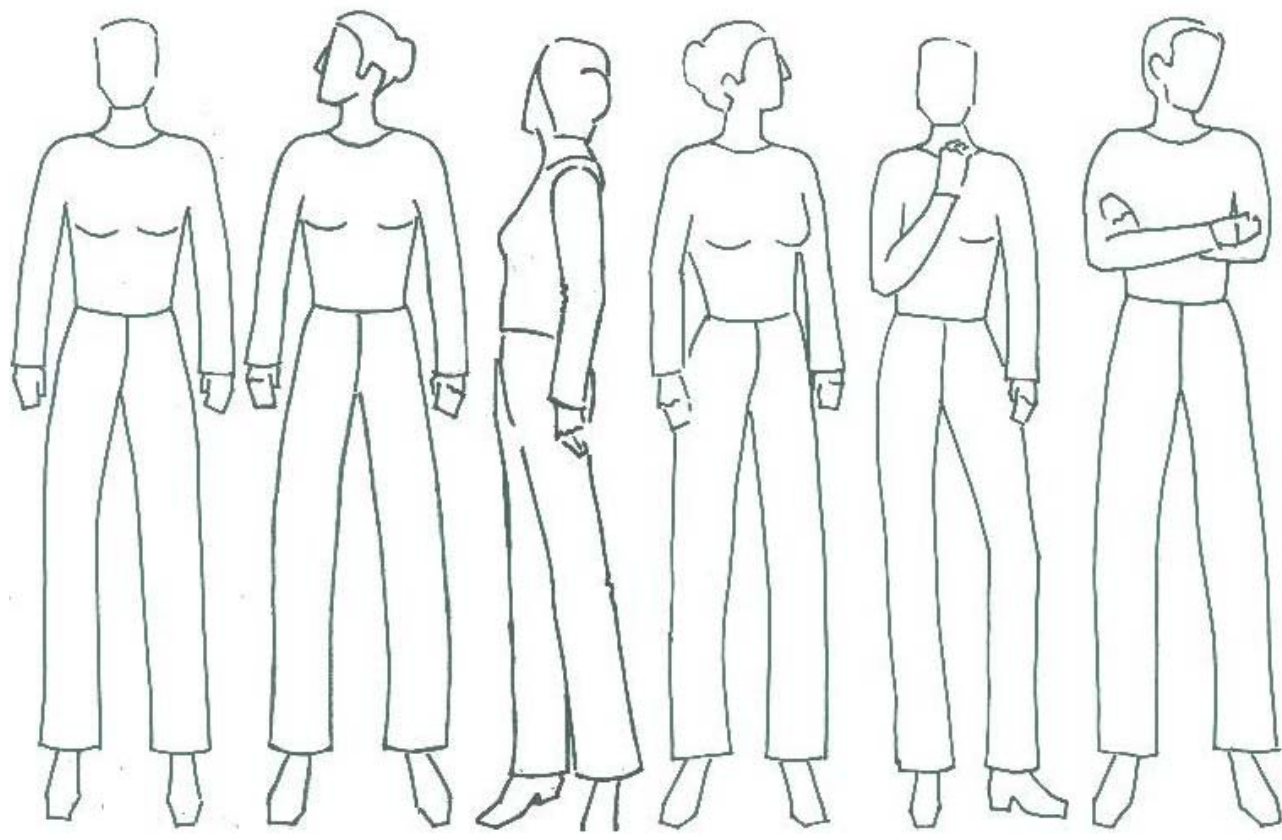

6. ábra. A felvett videoanyag lassú léptetésével két független asszisztens pontozta az egyes explorációs manőverek időtartamát és mértékét. Az előrehaladó egyenes tartáshoz képest, fokban meghatározva születtek meg a pontszámok egy konszenzuskonferencia eredményeként, kategóriánként összesítve azokat

17 A vizsgálatok a viselkedésterápiák kezdete során különböző módszerekkel végzett viselkedéselemzés és félelemhierarchia-felmérés részét alkották, amelyeket később, a megfelelő kognitív terápiás értelmezési módszerek támogatásával, in vivo deszenzitizációs vagy elárasztásos terápia követett. A betegek, a megfelelő tájékoztatást és a szükséges etikai engedélyek beszerzését követően, várólistáról kerültek be a vizsgálatba. 
ha a biztonságos és jól ismert területtől távol kell vállalt vagy kikényszerített feladatokat megoldani. A labirintusséta közben rögzített videofelvételek értékelése során a fej- és törzsfordításokkal járó keresgélést, a töprengés közben megjelenő sajáttest-érintést (simogatás, kaparászás, nyaklánccal, órával való játék), karba font kézzel való közlekedést, exploratív mozdulatokat elemeztük (6. ábra). Szorongó és nem szorongó személyek alagsori labirintusban végzett explorációs mozgásainak elemzése alapján megállapítottuk, hogy a pániktól és agorafóbiától szenvedő személyek menet közben, más csoporthoz képest hosszabb ideig, a testük előtt összekulcsolt kézzel haladtak (2. táblázat). Tehát olyan tartást vettek fel, amely elzárta őket a környezetben lévő tárgyak, épületrészek haptikus explorációjától. A labirintusséta előtt és után felvett vérnyomásértékek a pániktól és agorafóbiától szenvedőknél (PA), a generalizált szorongókhoz (GSZ) és a kontrollcsoporthoz képest magasabbak, ugyanakkor a GSZ és a kontrollcsoport között nincs számottevő különbség. ${ }^{18} \mathrm{Ez}$ az adat - a szorongásértékekkel kapcsolatos különbséget is figyelembe véve - hitelesíti azt a megállapítást, hogy a vizsgálatban kialakított labirintusséta speciális feladat elé állítja a pániktól és agorafóbiától szenvedő személyeket. Hasonló következtetésre juthatunk a csoportok között lévő navigációs különbségek alapján is (Kállai és mtsai, 1995, 2007) (2. táblázat).

Adataink szerint a pániktól és agorafóbiától szenvedő személyek téri tájékozódási képességének eredményességét több tényező hátráltatja: a) gyakori útvonalelvétések, $b$ ) emelkedett kardiovaszkuláris arousal és $c$ ) a feladat megoldását nem támogató testtartás, inadaptív explorációs műveletek. A személyek labirintusséta során rögzített mozgásának finomszemcsés elemzésekor a generalizált szorongó és a kontrollszemélyek többségénél megfigyelhető szabad és ritmikus kézmozgás nem volt látható a pánik és agorafóbiás személyeknél. Mellükön keresztbe font kezükkel szinte gúzsba kötötték testüket, megfosztva magukat a labirintus szabad explorációjának lehetőségétől.

Az ilyen, gesztusban kifejeződő, elzárkózó védekezéstípus részben tagadja a környezet realitását, és akadályozza a megközelítő viselkedés motivációinak és kognitív feltételeinek a megteremtését. Adataink bizonyítják, hogy a pániktól és agorafóbiától szenvedők labirintusban mutatott navigációs zavarai és fokozott kardiovaszkuláris arousal állapota, szorongása, a MARKS (1987) által leírt extraterritoriális viselkedéskészletre jellemző kognitív és motoros beállítódásokra vezethető vissza. A védekezés során a PA személy ignorálja az extraperszonális tér képének artikulációját, saját testi megnyilvánulásaira, periperszonális terének fenntartására koncentrál. Következésképpen egocentrikus referenciakeretéből csak fokozott erőfeszítések árán képes allocentrikus irányba átváltani.

\footnotetext{
18 Tapasztalataink szerint a generalizált szorongók, bízva az egyszerủ feladat során elérhető jó teljesítményükben, örömmel végezték a feladatot, a pániktól és agorafóbiától szenvedő személyek határozott diszkomfortról számoltak be, de egyik esetben sem kellett emiatt a felmérést megszakítani. Az „elárasztásos" technikák személyes alkalmazhatósága szempontjából pozitív véleményt tudtunk ezen eredmények alapján kialakítani.
} 
2. táblázat. Fiziológiai változók, explorációs viselkedés és navigációs különbségek a csoportok között (PA: pánik és agorafóbia; GSZ: generalizált szorongás; K: kontroll)

\begin{tabular}{|c|c|c|c|c|c|c|}
\hline & Vál t o z ó k & $\begin{array}{c}\text { 1. PA } \\
\text { átlag/szórás }\end{array}$ & $\begin{array}{c}\text { 2. GSZ } \\
\text { átlag/szórás }\end{array}$ & $\begin{array}{c}\text { 3. K } \\
\text { átlag/szórás }\end{array}$ & $\begin{array}{c}\mathrm{F} \\
\text { érték }\end{array}$ & $\begin{array}{c}\text { T-HDS } \\
\text { Post hoc }\end{array}$ \\
\hline$\underset{: 0}{: 0}$ & szisztolés vérnyomás & $128 \quad(16,8)$ & $114 \quad(10,2)$ & $116 \quad(12,7)$ & $4,68^{*}$ & $1-2$ \\
\hline$\frac{\vec{\pi}}{\pi}$ & diasztolés vérnyomás & $85,5 \quad(9,4)$ & $77,0 \quad(9,4)$ & $79,6 \quad(8,5)$ & $3,53^{*}$ & $1-2$ \\
\hline$\stackrel{2}{3}$ & szívritmus & $80,2 \quad(1,1)$ & $72,6 \quad(1,2)$ & $72,4 \quad(3,1)$ & 2,09 & \\
\hline$\underset{\Xi}{=}$ & szisztolés vérnyomás & $123 \quad(18,8)$ & $111 \quad(9,4)$ & $118 \quad(14,6)$ & 2,45 & \\
\hline$\underset{\frac{\pi}{\pi}}{\pi}$ & diasztolés vérnyomás & $86,3 \quad(9,9)$ & $74,7 \quad(9,0)$ & $80,6 \quad(9,6)$ & $5,57^{* *}$ & $1-2$ \\
\hline$\stackrel{n}{5}$ & szívritmus & $77,1 \quad(9,8)$ & $69,1 \quad(10,1)$ & $71,8 \quad(9,3)$ & 3,03 & \\
\hline Tö & rzsfordítás-gyakoriság & $2,83(0,6)$ & $1,1 \quad(0,3)$ & $1,2 \quad(0,2)$ & $3,77^{*}$ & $1-2$ \\
\hline & rzsfordítás-intenzitás & $58,0(14,7)$ & $25,0 \quad(12,3)$ & $44,2(15,6)$ & 1,93 & \\
\hline & fordítás-gyakoriság & $11,2 \quad(5,6)$ & $5,4 \quad(3,1)$ & $7,1 \quad(4,4)$ & $6,60^{* * *}$ & $1-2,1-3$ \\
\hline & fordítás-intenzitás & $72,1 \quad(10,1)$ & $66,9(20,0)$ & $72,0 \quad(23,8)$ & 0,38 & \\
\hline & ll elött keresztbe font & $57,2(16,8)$ & $14,5 \quad(7,7)$ & $9,2 \quad(5,6)$ & $5,51^{* *}$ & $1-2,1-3$ \\
\hline & iérintés & $2,1 \quad(1,1)$ & $1,9 \quad(0,5)$ & $1,8 \quad(0,8)$ & 0,10 & \\
\hline & prongás & $1,5 \quad(1,0)$ & $0,8 \quad(0,2)$ & $0,6 \quad(0,2)$ & $3,52^{*}$ & $1-3$ \\
\hline & vonaltévesztés & $86,4 \quad(7,6)$ & $95,7 \quad(6,3)$ & $96,8 \quad(7,9)$ & $11,11^{* *}$ & $1-2,1-3$ \\
\hline
\end{tabular}

" $p<0,05 ;{ }^{* *} p<0,01 ; \mathrm{df}=42$

\section{A szorongás virtuális valóságban végzett, helytanulásra kifejtett szelektív hatása pánik agorafóbiás személyeknél}

Az allocentrikus térkép alapú kontextus kiépítésének zavara más módon is megnyilvánult. A labirintusséta előtt és után virtuális valóság CGArena feladatot hajtottak végre a személyek, melyben a célpont eredményes megoldása csak allocentrikus reprezentáció kiépítésén keresztül volt lehetséges. Összehasonlítottuk a séta előtt közvetlenül, majd a komoly stresszt jelentő labirintusséta után felvett, computer által létrehozott virtuális navigációs teljesítményeket (CGArenal és CGArena2). Az eredmények szerint, annak ellenére, hogy a csoportok között a labirintusséta előtt a CGA teljesítmények számottevően nem különböztek, a pánik- 
tól és agorafóbiás tünetektől szenvedő betegek labirintusséta utáni teljesítménye, más csoportok eredményeihez képest jelentősen romlott (7. ábra). Eredményeink tehát rámutattak arra, hogy a pánik és agorafóbiás típusú stressz és a kognitív elkerülési stratégia eredményeként az aktuális környezet navigációs szignáljai dekontextualizálódnak, amelynek következményeként jentősen romlik az allocentrikus reprezentációk készítésének hatékonysága. Felvetődik a következő kérdés, ha egy feladatmegoldás során az allocentrikus stratégia alkalmazása lenne a kedvezőbb, mi akadályozza meg a személyt abban, hogy az általában használt egocentri kus keret használatáról allocentrikus referenciarendszer alkalmazására térjen át? Erre a kérdésre a thigmotaxis egocentrikus stratégiahasználat és a szorongás viszonyát tisztázó vizsgálatainkban kerestünk választ (KÁLLAI és mtsai, 2007), amely vizsgálat tapasztalatait a terápiás gyakorlat számára kialakított Figyelmi Fixációs Tréning javaslatainkban is igyekeztünk érvényre juttatni.

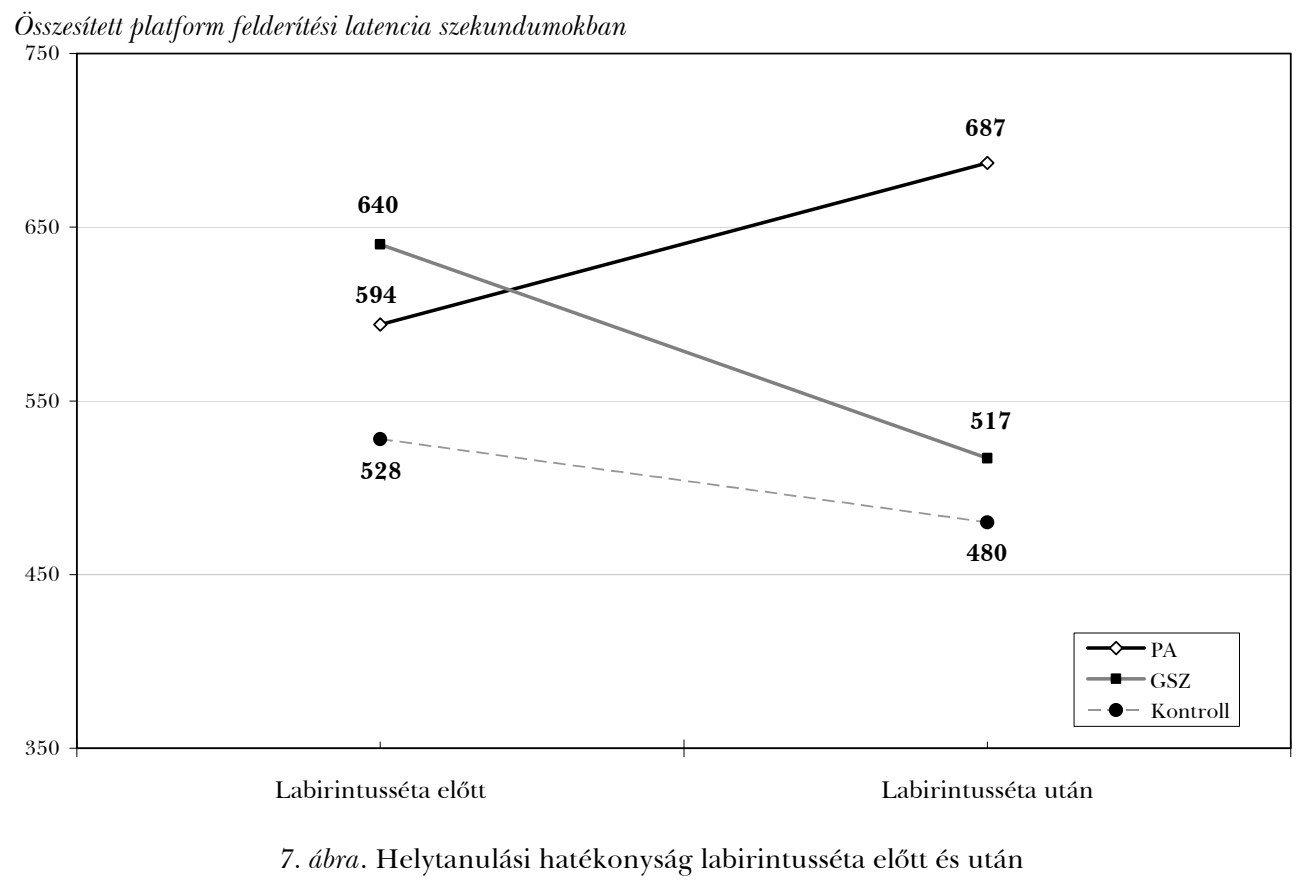

Helytanulás virtuális térben: labirintusséta előtt és után felvett CGAréna tesztben mutatott allocentrikus reprezentációs teljesítménykülönbségek pánikbetegek (PA), generalizált szorongók (GSZ) és kontrollszemélyek (K) között.

$$
\mathrm{F}_{(2,42)}=3,514 ; p<0,05 \text {. }
$$

KÁLLAI, KARÁDI és FELDMANN (2009). Anxiety-dependent spatial navigation strategies in virtual and real spaces. Cognitive Processing, 10(2), 229-232. 
A fenti kutatási eredmények figyelembevételével, a pániktól és agorafóbiától szenvedő személyek részére általunk kidolgozott téri orientációs fejlesztőprogram számol az egocentrikus és allocentrikus fixáció, valamint reprezentációs deficit jelenlétével. Az egocentrikus referenciarendszer merev alkalmazása beszúkíti az ember hatékony problémamegoldási lehetőségeit. Láttuk, hogy a szorongás csökkenti ezt a decentrálási, figyelmi allokációs fókuszpontváltások által kínált lehetőséget. Klinikai vizsgálataink során pániktól és agorafóbiától szenvedők számára, miközben valós élethelyzetben, utcán, bevásárlóközpontban tevékenykedtek, „mindfullness” alapelvekre épített figyelmi allokációs gyakorlatokat dolgoztunk ki. Ezek elemei: a) a részben kontextusát veszített negatív jelzőinger-tartalmú tárgyról pozitív kontextusba helyeztük át a figyelmet. A kellemetlen testi élmények felől külső, pozitív élmények felé irányítja a személy ilyenkor a figyelmét. Ez a pozitív céltárgy fókuszba állítása gyakorlat; $b$ ) a fókuszba hozott tárggyal kapcsolatosan elindítottunk egy asszociációs sort, amelynek stációi az adott tárggyal kapcsolatos, múltban gyökerező emlékek felidézése. Azt követően a pozitív tárgy fókuszban tartása mellett a jelenre, majd a jövőre vetítve is kértük az asszociációk téri és idői tartalmainak kifejtését. Ez a téri-idői aktualizáció gyakorlat, amely a jelen fókuszában lévő tárgy vagy személy észlelésének affektív és kognitív tartalmait az autobiográfiai memória tartalmaival gazdagítja. Élményközelivé teszi a személy tevékenységének kontextusát; $c$ ) a harmadik lépésben, a fent már említett in vivo környezetben - például egy szupermarket polcrengetegének közepén - kértük, hogy a résztvevő lehetőleg pontosan határozza meg a különböző égtájak irányát, pénztárak, be- és kijárati ajtók helyét, fejben készítsen egy térképet magának a környezetéről, a fontos navigációs tárgyak elhelyezésével együtt. Ez a topográfiai analízis gyakorlat, amelynek célja, hogy a korábbiakban a kellemetlen testi állapotról külső tárgyra irányított, idői és téri távlatokba helyezett artikulált kontextust a személy, allocentrikus referenciarendszerek felhasználásával, ismerős, átlátható közeggé transzformálja. A gyakorlatok elméleti konstruktuma JACOBS és NADEL (1985), Tringer és MórotZ (1985), BECK (1988), KÁLlAi és MOLNÁR (1991) munkáiból származtatható.

\section{AZ EREDMÉNYEK KLINIKAI FELHASZNÁLÁSA. ÖSSZEGZÉS ÉS KITEKINTÉS}

Befejezésül hadd szóljak néhány szót a fentiekben felsorolt eredmények klinikai felhasználhatóságáról. A téri tájékozódás mechanizmusainak empirikus elemzése alapján állíthatjuk, hogy a valós és a virtuális térben végzett navigáció, helytanulás, epizódok egymáshoz illesztése hasonló elvek alapján szerveződik. A virtuális valóságban szerzett tapasztalatok, bizonyos megszorításokkal, közvetlenül beilleszthetők a fizikailag valós térben és időben zajló tevékenység szervezésébe, problémák megoldása és pszichoterápiás tevékenység kivitelezése során egyaránt. Fel kell azonban hívni a figyelmet arra, hogy az egyre kifinomultabb médiadesign eredményeként a valós és a virtuális környezet hasonlósága intenzívebb, mint gondolnánk. A computer által létrehozott virtuális környezetben végzett tevékeny- 
ség képességeket fejleszt, vágyakat indukál, értékeket közvetít, tárgykapcsolatokat kínál. Ez a világ nem csak erényeinek felmutatásában erős, de a valós emberi viszonyokhoz képest a hiányokat is markánsabban jeleníti meg, de csak azok számára, akik érzékenyek e különbségek felfogására. Az emberek egy része az említett különbségekre, kontrasztokra érzéketlen. Gyakran összemossák a határokat, és illúziók rabjaivá válnak. Számos példát látunk erre a személyiségzavar-spektrum területéről, amelyek elsősorban a szkizotípiás és a borderline személyiségszerveződés esetén mutatkoznak meg (UNOKA, FOGD, SERES, KERI és CsuKLY, 2014).

Jelenlegi kutatásaink a sajáttest- és testrész-élmény kognitív idegtudományi mechanizmusait elemzik. A valós és virtuális környezetben létrehozható sajáttestillúziók multimodális integrációs mechanizmusait vizsgáljuk. Elemzéseink tárgya az ember periperszonális környezetének, személyes határainak konstrukciója, stabilitása és kiterjedése. Klinikai tapasztalatok mutatják, hogy az emberek egy csoportja az átmeneti kötődési tárgyak özönében nem tudja kezében tartani, megfelelő tudatossággal kezelni énje határait és autobiográfiájuk alapján felépített realitását. Mindezek fényében talán nem okoz meglepetést a fokozott tudatos jelenlétre, az itt és most történéseibe való felelősségteljes személyes részvételre (mindfulness, agency, sémarekonstrukció) épített kapcsolatfejlesztő és pszichoterápiás beavatkozások határozott előtérbe kerülése (PERCZEL, 2011). Az általunk bemutatott eredmények alapján kidolgozott, és a klinikai gyakorlatban alkalmazott Figyelmi Fixációs Tréning és kiegészítő módszerei (KáLLAI, KosZTOLÁNYI, OSVÁTH és JACOBS, 1999; KÁlLAI és mtsai, 2015) a kognitív alapzavarok egyik korrekciós módját ígérik, jól illeszkednek a mindfulness terápiás vonulat egészéhez. Úgy gondolom, a valós vagy virtuális környezetben előtérbe állított pozitív töltésű epizód idői dimenzióinak felszínre hozása, (jelen, múlt, jövő kontextus éber meditatív idői és téri aktualizációja) felfrissít egy koherens kognitív folyamatot. Más oldalról, a környezet fizikai paramétereinek és a test topológiai helyzetének aktualizációja elősegíti, hogy a fejlesztési folyamatban a személy a virtuális vagy a szubjektív egocentrikus pozíciót meghaladva, a valós körülmények között talpon maradhasson, és ne szálljon el mások számára ismeretlen virtuális világok felé. Ne csak első személyben, de harmadik személyű perspektívából is meg tudja szólítani önmagát.

\section{IRODALOM}

Andersen, P., Morris, R., Amaral, D., Bliss, T., \& O’Keefe, J. (2007). The hippocampus book. Oxford: Oxford University Press.

BeCK, A. T. (1988). Cognitive approach to panic disorder: Theory and therapy. In S. Rachman, \& D. MASER (Eds.), Panic Psychological perspectives (91-109). London: Lawrence Erlbaum.

Bonnevie, T., Dunn, B. A., Fyhn, M., Hafting, T., Derdikman, D. M., Kubie, J. L., Roudi, Y., Moser, E. I., \& Moser, M-B. (2013). Grid cells require excitatory drive from the hippocampus. Nature Neuroscience 16(3), 309-317.

Burgess, N. (2006). Spatial memory: how egocentric and allocentric combine. Trends in Cognitive Sciences, 10(12), 551-557. 
Burgess, N., Maguire, E. A., \& O'Keefe, J. (2002). The human hippocampus and spatial and episodic memory. Neuron, 34, 625-641.

Buzsáki, Gy, (2002). Theta oscillations in the hippocampus. Neuron, 33, 325-340.

BuZSÁki, GY. (2011). Rhythms of the Brain. Oxford: Oxford University Press.

Couey, J. J., Witoelar, A., Zhang, S-J., Ye, J., Dunn, B., CZajkowski, R., Moser, M-B., Moser, E. I., Roudi, Y., \& WitTer, M. P. (2013). Recurrent inhibitory circuitry as a mechanism for grid formation. Nature Neuroscience, 16(3), 318-324.

Freund, T. F., \& BuZsáki, Gy. (1996). Interneurons of the hippocampus. Hippocampus, 6, $347-470$.

Fyhn, M., Molden, S., Witter, M. P., Moser, E. I., \& Moser, M-B. (2004). Spatial representation in the entorhinal cortex. Science, 305, 1258-1264.

Grastyán, E., Lissák, K., Madarász, I., \& Donhoffer, H. (1959). Hippocampal electric activity during the development of conditioned reflexes. Encephalography and Clinical Neurophysiology, 11, 409-430.

JACOBS, W. J., \& NADEL, L. (1999). The first panic attack: a neurobiological theory. Canadian Journal of Experimental Psychology, 53(1), 92-107.

Jacobs, L. F., \& Schenk, F. (2003). Unpacking the cognitive map: The parallel map theory of hippocampal function. Psychological Review, 110(2), 285-315.

Jacobs, W. J., \& NAdel, L. (1985). Stress-induced recovery of fears and phobias. Psychological Review, 9(4), 512-531.

KÁllai J. és MolnÁr P. (1991). A környezetről kialakított kognitív térkép megszerkesztésének hiányosságai agorafóbiás személyeknél. Ideggyógyászati Szemle, 44, 297-302.

Kállai J., SZabó I., VARGa J., Molnár P. és Kóczán Gy. (1995). Pánik agorafóbiás személyek téri tájékozódásának empirikus vizsgálata. Psychiatria Hungarica, 3, 243-249.

Kállai, J., Kosztolányi, P., OSváth, A., \& Jacobs, W. J. (1999). Attention fixation training: training people to form cognitive maps help to control symptoms of panic disorder with agoraphobia. Journal of Behavior Therapy and Experimental Psychiatry, 30(4), 273-288.

Kállai J. (2004). A téri tájékozódás és a szorongás. Budapest: Janus/Gondolat Kiadó.

Kállai, J., MakÁNY, T., KarÁdi, K., \& JacobS, W. J. (2005). Spatial Orientation Strategies in Morris-type Virtual Water Task for Humans. Behavioral Brain Research, 159(2), 187-196.

Kállai, J., Kázmér, K., Bereczkei, T., Rózsa, S., Jacobs, W. J., \& NAdel, L. (2007). Spatial exploration behaviour in an extended labyrinth in patients with panic disorder and agoraphobia. Psychiatry Research, 149, 223-230.

Kállai, J., Makány, T., Csathó, A., Horváth, D., Karádi, K., Lábadi, K. B., Járai, R., NADEL, L., \& JACOBS, W. J. (2007). Cognitive and affective aspects of thigmotaxis strategy in humans. Behavioral Neuroscience, 121, 21-30.

KÁlLAI J. (2013). Társas kapcsolatok neuropszichológiája. Budapest: Medicina Kiadó.

Kállai, J., Hegedüs, G., Feldmann, Á., Rózsa, S., Darnai, G., Herold, R., Dorn, K., Kincses, P., CsATHÓ, Á., \& SzOlCSÁNYi, T. (2015). Temperament and psychopathological syndromes specific susceptibility for Rubber Hand Illusion, Psychiatry Research, 229(1-2), 410-419.

Leutgeb, S., Leutgeb, J. K., Barnes, C. A., Moser, E. I., McNaughton, B. L., \& Moser, M-B. (2005). Independent codes for spatial and episodic memory in hippocampal neuronal ensembles. Science, 309, 619-623. 
Maguire, E. A., Frackowiak, R. S., \& Frith, C. D. (1998). Learning to find your way: a role for the human hippocampal formation. Proceedings of the Royal Society of London B: Biological Sciences 263, 1745-1750.

Maguire, E. A., Gadian, D. G., Johnsrude, I. S., Good, C. D., Ashburner, J., FrackoWIAK, R. S., \& FRITH, C. D. (2000). Navigation - related structural change in the hippocampi of taxi drivers. Proceedings of the National Academy of Sciences, 97, 4398-4403.

MAKÁNY, T., \& KÁllaI, J. (2004). Human spatial orientation and way-finding analysis with Ethovision in a Real Arena Maze. Noldus New, 1, 3-4.

MARKs, I. M. (1987). Fears, phobias and rituals. New York: Oxford University Press.

Meilinger, T., \& Vosgerau, G. (2010). Putting egocentric and allocentric into perspective. In C. Hölscher et al. (Eds.), Spatial Cognition VII. LNAI 6222 (207-221). Berlin: Springer Verlag.

Morris, R. G. M. (1984). Development of a water-maze procedure for study spatial learning in the rat. Journal of Neuroscience Methods, 11, 47-60.

Nadel, L., Thomas, K. G. F., Laurance, H. E., Skelton, R., Tal, T., \& Jacobs, W. J. (1998). Human Place Learning in a Computer Generated Arena. In C. Freksa, C. HABEL, K. WENDER (Eds.), Spatial Cognition. An Interdisciplinary Approach to Representing and Procesing Spatial Knowledge (399-427). Berlin: Springer Verlag.

Noldus, L., Spink, A. J., \& Tegelenbosch, R. (2001). Etho Vision: A versatile video tracking system for automation behavioral experiments. Behavior Research Methods, Instruments and Computers, 33(3), 398-414.

O'KeEfe, J., \& NADEL, L. (1978). The hippocampus as a cognitive map. Oxford: Clarendon Press.

O'KeEFe, J. (1991). An allocentric spatial model for the hippocampal cognitive map. Hippocampus, 1(3), 230-235.

O'Keefe, J., \& Dostrovsky, J. (1971). The hippocampus as a spatial map. Preliminary evidence from unit activity in the freely-moving rat. Brain Research, 34, 171-175.

Olds, J., \& Milner, P. (1954). Positive reinforcement produced by electrical stimulation of septal area and other regions of rat brain. Journal of Comparative and Physiological Psychology, 47, 419-27.

PAILlard, J. (1991). Knowing where and knowing how to get there. In J. PAILlard (Ed.), Brain and Space (461-481). New York: Oxford University Press.

Perczel Forintos D. (2011). A kognitív terápia fénykora: a második és harmadik hullám. Magyar Pszichológiai Szemle, 66(1), 11-29.

Petkova, V. I., BJörnsdotter, M., Gentile, G., Jonsson, T., Li, T. Q., \& Ehrsson, H. H. (2011). From part-to whole-body ownership in the multisensory brain. Current Biology, 21, 1118-1122.

SCOville, W. B., \& Milner, B. (1957). Loss of recent memory after bilateral hippocampal lesions. Journal of Neurology, Neurosurgery \& Psychiatry 20(1), 11-21.

Thinus-Blanc, C., \& Gaunet, F. (1997). Representation of space in blind persons: vision as a spatial sense? Psychological Bulletin, 121, 20-42.

Thomas, K. G. F., Hsu, M., Laurance, H. E., Nadel, L., \& Jacobs, W. J. (2001). Place learning in virtual space III: Investigation of spatial navigation training procedures and their application to $f$ MRI and clinical neurpsychology. Behavioral Research Methods, Instruments, and Computers, 33(1), 21-27. 
Tolman, E. C. (1948). Cognitive maps in rats and man. The Psychological Review, 55(4), 189-208.

Tringer L. és Mórotz K. (1985). Klinikai viselkedésterápiák. Budapest: Magyar Pszichiátriai Társaság.

Unoka, Zs., Fogd, D., Seres, I., Keri, Sz., \& Csukly, G. (2014). Early Maladaptive Schema-Related Impairment and Co-Occurring Current Major Depressive EpisodeRelated Enhancement of Mental State Decoding Ability in Borderline Personality Disorder. Journal of Personality Disorders, ([Epub ahead of print]) 1-18.

Zhang, S-J., Ye, J., Miao, C., Tsao, A., Cerniauskas, I., Ledergerber, D., Moser, M-B., \& Moser E. I. (2013). Optogenetic dissection of entorhinal-hippocampal functional connectivity. Science, 340(6128), 1232627.

\title{
REALITY AND FICTION: SPATIAL ORIENTATION IN REAL AND COMPUTER-GENERATED VIRTUAL ENVIRONMENT
}

\author{
KÁLLAI, JÁNOS
}

The presentation intends to provide a short overview of cognitive neuroscience research results in spatial orientation, and introduces its most significant contributors. After discussing neuroscience examples and the history of science of spatial learning, the presentation will detail the multidimensional features of spatial memory. It will investigate the dynamic changes of the egocentric-allocentric representations and the clinical aspects of attentional foreground and background, as well as the interaction of anxiety and spatial orientation. The discussed data intends to call attention to certain current issues of the coming decades. How to adjust to the ever more frequently encountered computed-generated realities? How the general perspective on space may help the automatisms of detachment or fusion of the self? What may researchers benefit from advanced virtual reality that offers tactile, auditive and proprioceptive stimuli?

Key words: egocentric, allocentric, place learning, anxiety, navigation strategy, agoraphobia 